\title{
Bilateral Inflammatory Pseudotumour of the Breast: A Case Report and Review of the Literature
}

\author{
Mohsin Dani, Sarah Pinder, Ian Fentiman \\ Department of Research Oncology, Guy's Hospital, London, England
}

\begin{abstract}
Inflammatory tumour (IPT) consists of spindle cells, mature plasma cells, histiocytes, lymphocytes and eosinophils. Most frequently presenting in the respiratory tract it can also affect other sites such as breast. This case was a 73-year old woman presenting with a left breast lump, clinically indeterminate (P3), proven on biopsy to be IPT. Seven years later she returned with bilateral breast lumps and underwent triple assessment followed by wide excisions which confirmed the diagnosis of IPTs. Because it can be difficult to differentiate IPT from a low-grade spindle cell metaplastic breast carcinoma $(\mathrm{SpCMBC})$ wide excision to achieve clear margins should be achieved to exclude malignancy.
\end{abstract}

Keywords: Breast, inflammatory myofibroblastic tumour, inflammatory pseudotumour, breast cancer

Cite this article as: Dani M, Pinder S, Fentiman I. Bilateral Inflammatory Pseudotumour of the Breast: A Case Report and Review of the Literature. Eur J Breast Health 2018; 14(4): 229-233.

\section{Introduction}

Inflammatory pseudotumour (IPT) is a rare benign condition usually seen in the lungs and airways of young individuals. There is a multiplicity of nomenclature for this lesion including pseudomalignant spindle cell proliferation, plasma cell granuloma, post-inflammatory tumour, pseudosarcomatous fibromyxoid tumor, nodular fasciitis, inflammatory pseudotumour, post-operative spindle cell nodule, or pseudosarcomatous myofibroblastic proliferation (1).

It comprises spindle cells admixed with mature plasma cells, histiocytes, lymphocytes and eosinophils. Extrapulmonary sites include the gastrointestinal tract, urinary tract, retroperitoneum, peritoneum, mesentery, pancreas, spinal cord meninges, intracranial spaces, liver, thyroid, spleen and lymph nodes (1). It occurs very rarely in the breast and was first described by Pettinato et al. (2) in 1988. Bilateral inflammatory pseudotumour of the breast has been reported in only two previous cases $(1,2)$. Treatment is usually excision biopsy because many are suspected pre-operatively to be malignant.

\section{Case Presentation}

A 73-year-old woman was initially seen in 2004 in the Breast Clinic at Guy's Hospital with a right breast lump. This measured 15 mm clinically and mammograms and ultrasound revealed a suspicious abnormality (E3, M3, U4). She underwent ultrasound-guided core biopsies and these showed acute and chronic inflammation so the patient was reassured. The lump persisted and was re-imaged in 2005. Imaging was reported as showing signs of unequivocal malignancy (M5, U5), (Table 1). Repeat core biopsy showed chronic inflammation and fibrosis. Imprint cytology however showed atypia (C3) with few small cohesive groups of epithelial cells with superimposed myoepithelial cells, mild nuclear atypia, and fragments of degenerate, vascularised connective tissue stroma.

The patient was advised to have an excision biopsy of the lump to which she agreed. Histology showed an ill-defined lesion composed of an irregular proliferation of fibrous connective tissue associated with severe inflammatory reaction. The spindle cells were without atypia or significant mitotic activity. The inflammatory component consisted of plasma cells, lymphocytes and eosinophils. Additionally, there was inflammatory cell infiltration of blood vessel walls. Immunohistochemistry showed the lymphocytic infiltrate to be polyclonal and light chain restriction was not demonstrated. Final histology was in keeping with an inflammatory pseudotumour (IPT). 
Table 1. Sequential triple assessment findings in patient with IPT

\begin{tabular}{lccccc} 
Year & Clinical & Mammo & USS & Cytology & Core \\
\hline 2004 & RE3 & RM3 & RU4 & RC3 & B2 \\
& LE1 & LM2 & LU1 & & \\
2005 & RE4 & RM5 & R U5 & R C3 & \\
& LE1 & LM1 & LU1 & & \\
2007 & RE2 & RM2 & R U2 & - & \\
& LE1 & LM1 & LU1 & & \\
2011 & RE3 & RM3 & R U5 & & R B2 IPT \\
& LE1 & LM4 & LU5 & & L B2 IPT \\
\hline
\end{tabular}

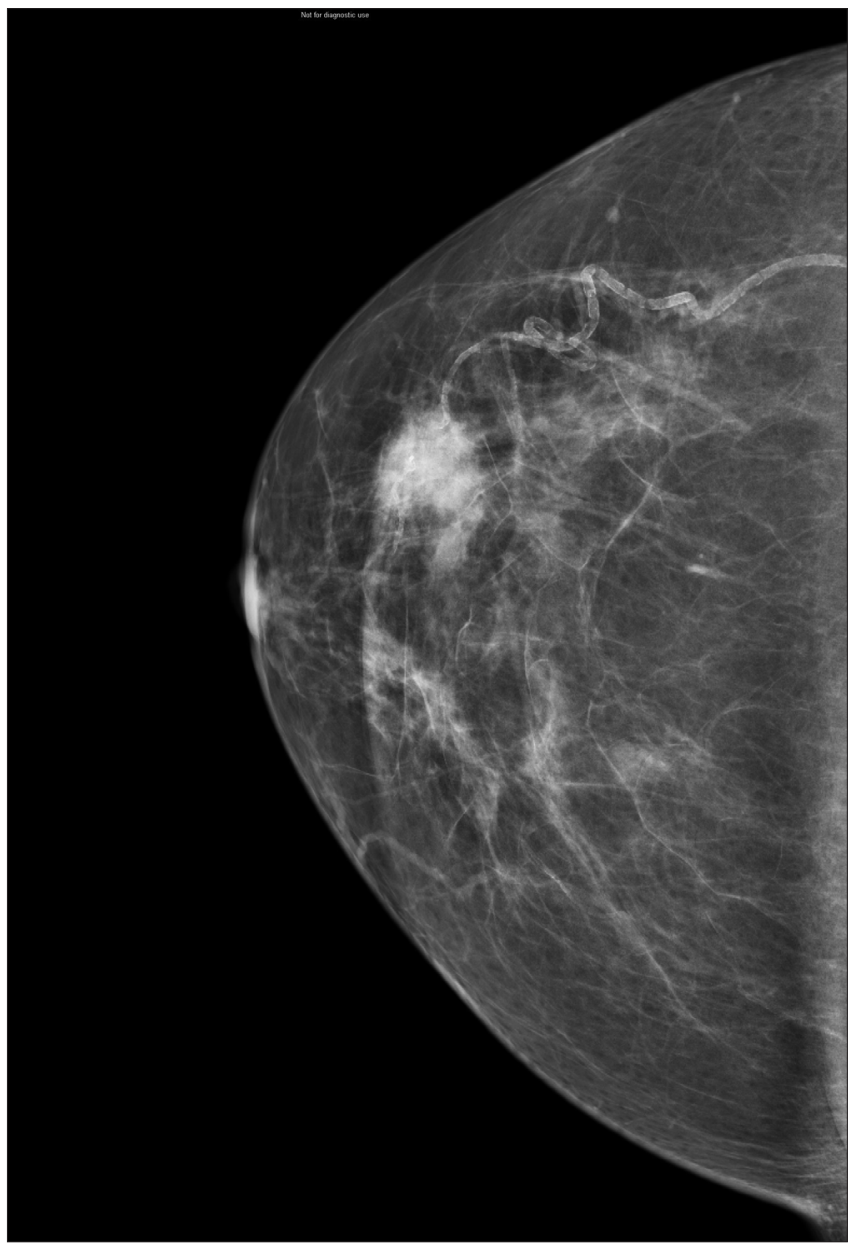

Figure 1. Right mammogram CC view

During follow-up in 2007 she was asymptomatic and there was no abnormality on clinical examination. Bilateral mammograms and breast USS showed benign changes only (M2, U2). She was reassured and discharged.

She returned to the Breast Clinic in 2011 giving a 3-month history of right breast lump. On clinical examination there was a $15-\mathrm{mm}$ mass lateral to the biopsy scar in the upper outer quadrant of right breast. The mass was hard with an irregular surface, but not fixed to skin or chest wall. Right mammogram (MMG) (Figure 1,2) showed an indeterminate (M3) area of increased density in the upper outer aspect. Left MMG (Figure 3, 4) showed a new area of suspicious asymmetrical

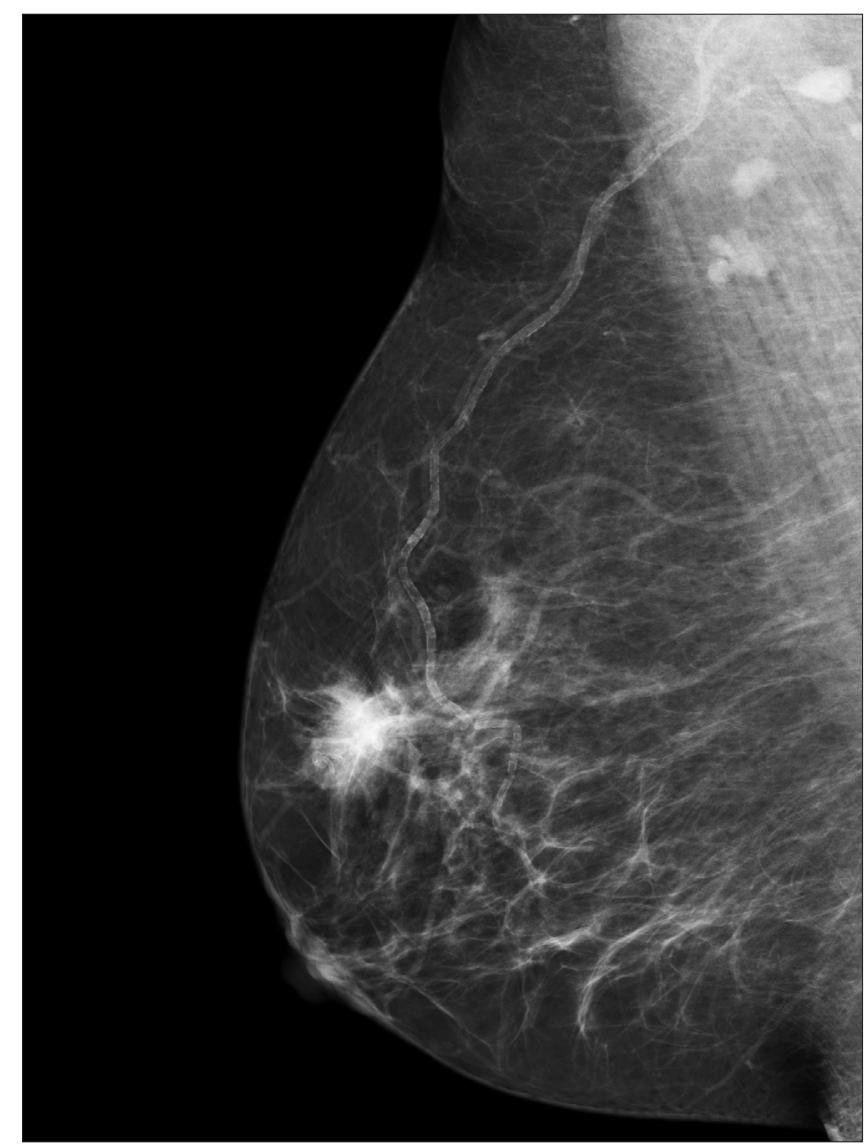

Figure 2. Right mammogram MLO view

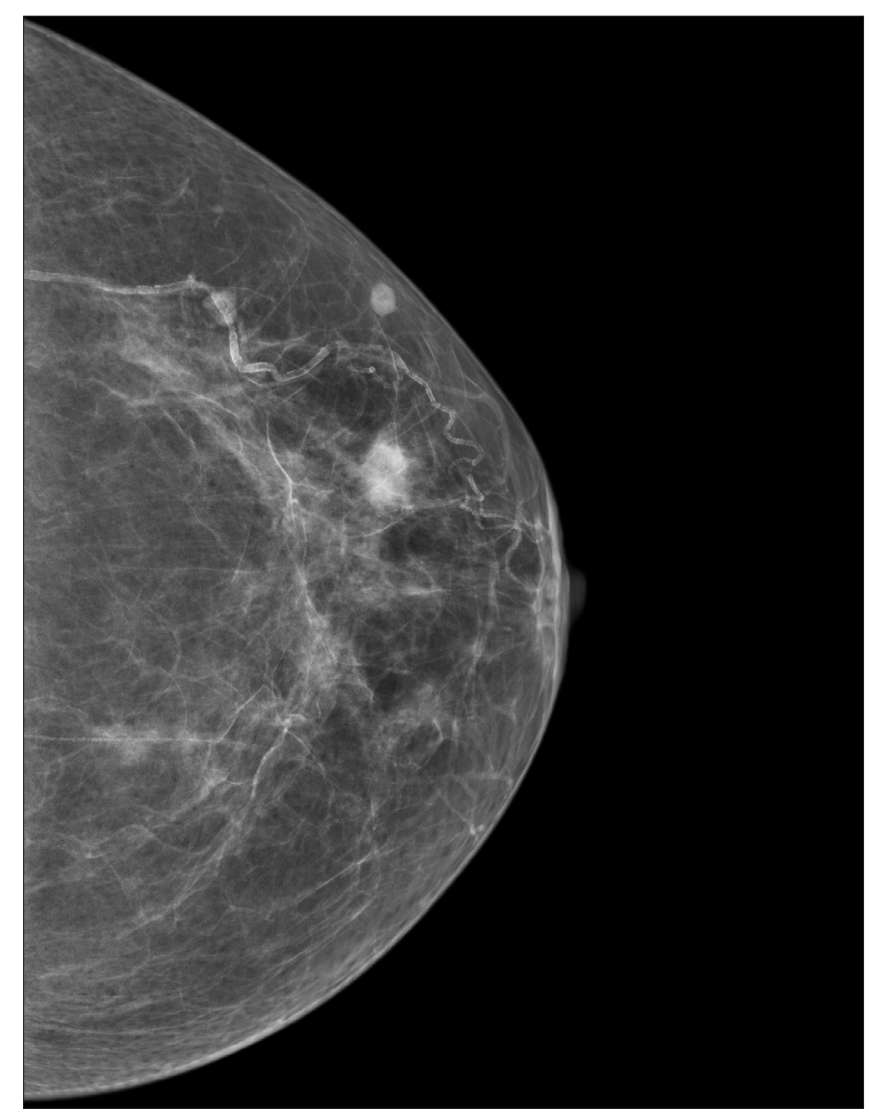

Figure 3. Left mammogram CC view 
Table 2. Patients with inflammatory pseudo tumours of the breast

\begin{tabular}{|c|c|c|c|c|c|c|c|c|c|}
\hline Author & Patient age & Side & Size (mm) & SMA & Surgery & IgG4 & ALK & PAN CK & Follow-up (years) \\
\hline Pettinato 1988 & 29 & $\mathrm{R}$ & & + ve & $\mathrm{e} / \mathrm{b}$ & & & & 2.5 \\
\hline Coffin 1995 & 13 & $\mathrm{R}$ & & & e/b & & & & 1 \\
\hline Bisceglia 1995 & 38 & & & & $\mathrm{e} / \mathrm{b}$ & & & & \\
\hline \multirow[t]{3}{*}{ Chetty 1997} & 16 & $\mathrm{R}$ & 20 & + ve & e/b & & & & 1 \\
\hline & 18 & $\mathrm{R}$ & 20 & +ve & $\mathrm{e} / \mathrm{b}$ & & & & 1 \\
\hline & 46 & $\mathrm{R}$ & 80 & + ve & e/b & & & & 0.5 \\
\hline Yip 1997 & 66 & Bil & $30 / 20$ & & $\mathrm{e} / \mathrm{b}$ & & & & 0.75 \\
\hline Gobbi 1999 & 86 & $\mathrm{~L}$ & & & $\mathrm{e} / \mathrm{b}$ & & & & \\
\hline Sastre-Garau 2002 & 64 & $\mathrm{R}$ & 20 & + ve & e/b & & -ve & -ve & \\
\hline Zardawi 2003 & 79 & Bil & & & $\mathrm{e} / \mathrm{b}$ & & & & 9 \\
\hline Haj 2003 & 31 & $\mathrm{R}$ & 60 & & e/b & & & -ve & - \\
\hline Zen 2005 & 46 & $\mathrm{~L}$ & 16 & & e/b & + ve & & & 1 \\
\hline Ilvan 2005 & 60 & $\mathrm{R}$ & 10 & & $\mathrm{e} / \mathrm{b}$ & & & -ve & 7 \\
\hline \multirow[t]{3}{*}{ Khanafshar 2005} & 33 & $\mathrm{~L}$ & & + ve & e/b & & -ve & -ve & \\
\hline & 47 & $\mathrm{R}$ & & + ve & e/b & & -ve & -ve & \\
\hline & 75 & $\mathrm{~L}$ & & + ve & $\mathrm{e} / \mathrm{b}$ & & -ve & -ve & \\
\hline Akbulut 2007 & 38 & $\mathrm{~L}$ & 10 & + ve & $e / b$ & & -ve & -ve & 1 \\
\hline Park 2009 & 47 & $\mathrm{R}$ & 30 & + ve & $\mathrm{e} / \mathrm{b}$ & & -ve & -ve & 3 \\
\hline Kim 2009 & 60 & L & 15 & + ve & $\mathrm{e} / \mathrm{b}$ & & -ve & -ve & 2 \\
\hline Hill 2010 & 53 & $\mathrm{R}$ & 50 & +ve & $\mathrm{e} / \mathrm{b}$ & Sparse & -ve & & - \\
\hline Sari 2011 & 54 & $\mathrm{~L}$ & 30 & + ve & $\mathrm{e} / \mathrm{b}$ & & & +ve & $1 / 3$ \\
\hline Vecchio 2011 & 22 (male) & $\mathrm{L}$ & 70 & + ve & $\mathrm{e} / \mathrm{b}$ & & -ve & & $10 / 12$ \\
\hline \multirow[t]{2}{*}{ Chougule 2015} & 66 & $\mathrm{~L}$ & 30 & -ve & e/b & $+v e$ & -ve & & 1.5 \\
\hline & 45 & $\mathrm{R}$ & 15 & -ve & $\mathrm{e} / \mathrm{b}$ & +ve & -ve & & 1 \\
\hline Greenleaf 2016 & 69 & $\mathrm{R}$ & 23 & & $\mathrm{e} / \mathrm{b}$ & & & & - \\
\hline Goto 2016 & 52 & L & 30 & & Steroid & & & & 0.75 \\
\hline Present case & 73 & Bil & 30 & $+v e$ & e/b & + ve & -ve & -ve & 7 \\
\hline
\end{tabular}

density (M4) in the upper outer aspect. These findings were confirmed on compression views. Breast ultrasound scan (USS) confirmed 14x15 $\mathrm{mm}$ irregular, hypoechoic, highly vascular solid mass (U4) on the right and $12 \times 9 \mathrm{~mm}$ irregular, hypoechoic lesion (U5) on the left (Table 1). Core biopsies were taken from both the lesions under USS control. Both biopsies showed features similar with those in the surgical specimen from 2005 of fibrotic breast tissue with a spindle cell proliferation and associated chronic inflammatory cell infiltrate. There was no atypia or mitotic activity. The inflammatory infiltrate consisted of plasma cells, lymphocytes and eosinophils.

Immunohistochemistry showed mild infiltrate of IgG4 positive plasma cells in the right breast lesion (8 IgG4 positive cells per HPF) and a moderate infiltrate in left breast specimen (11 IgG4 positive cells per HPF). Bilateral wide excision of the lesions was performed. Because the right sided specimen was close to all margins a re-excision was

\section{Discussion and Conclusion}

Only 27 cases have been previously reported in the English literature and the outline details of these and the present case are given in Table 2 (1-20). Median age was 47 years (range 13-86) with 14 aged $<50$ years and 13 aged $\geq 50$. Of the unilateral cases with known laterality, 13 were right-sided and 10 located on the left so that this does not mirror the slightly increased frequency of left sided breast cancers (1). This is the third case, in whom, after initial surgical excision of IPT from one side, the patient subsequently presented with bilateral recurrence (4, 5). Treatment was almost always excision biopsy but Goto et al. (21) treated the patient with prednisolone after core biopsy with resolution of the lump.

Vecchio et al. (1) recently described the first male case with a large mass occurring after trauma. The most striking histological features was the presence of large pleomorphic cells with hypercellularity and 


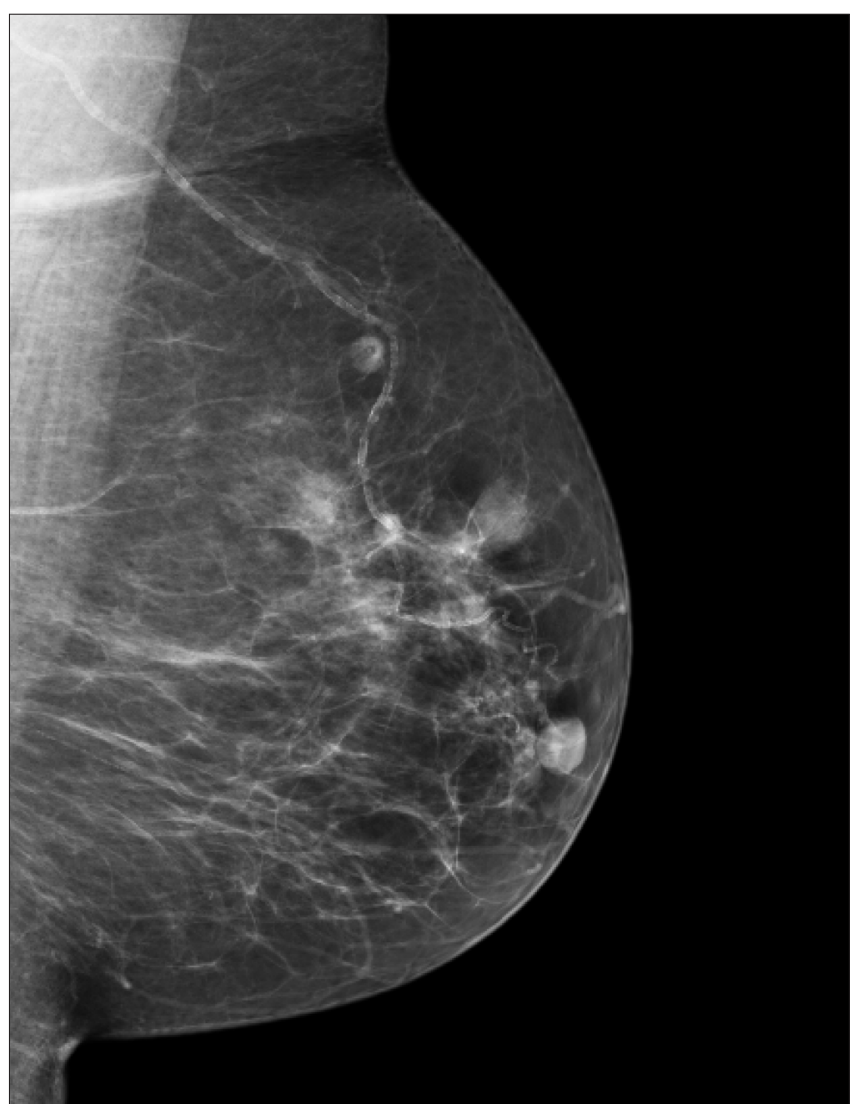

Figure 4. Left mammogram MLO view

a prominent fascicular pattern. The lesion bore a close resemblance to inflammatory myofibroblastic tumor (IMT) with atypical features but was negative for ALK-1 protein on immunohistochemistry. The potential for misdiagnosis and the broader spectrum of morphology in IPT was stressed.

Immuno-histochemistry is important in diagnosis of this entity as histological features are consistent with chronic fibrosis and inflammation. Presence of myofibroblasts has been confirmed in almost all cases by SMA positivity. Serum IgG4 has been shown to be high in IPT of breast (11) however in this case, levels were within the normal range preoperatively. The association between IgG4 and IPT was first reported in pancreatic pseudotumour, also known as sclerosing pancreatitis. Serum IgG4 was shown to be significantly and specifically higher in patients with sclerosing pancreatitis, compared to other pancreatic conditions (22).

Inflammatory pseudotumour has generally been regarded as a benign condition, but is known to recur. In some cases, there is local inflammation with systemic symptoms that resolve after resection. SastreGarau et al. (9) carried out a cytogenetic analysis of a breast IPT and found that the lesion was clonal with a $9 \mathrm{p}$ deletion and suggested that this was a low grade malignant lesion. Reis-Filho (23) however pointed out that clonal origin was not necessarily an indication of malignancy and that because the tumour described by Sastre-Garau et al. (9) had been incompletely characterised in terms of p63, maspin, E- and Pcadherin expression, it was possible that the lesion was a low-grade spindle cell metaplastic breast carcinoma (SpCMBC) (24). Hence differentiation from malignant condition along with wide excision to achieve clear margins should be the diagnostic and therapeutic aims in the management of this rare benign breast condition
Informed Consent: Written informed consent was obtained from patient who participated in this study.

Peer-review: Externally peer-reviewed.

Author Contributions: Concept - M.D., I.F.; Design - M.D., I.F.; Supervision - S.P., I.F.; Resources - S.P.; Materials - S.P.; Data Collection and/or Processing - S.P., I.F.; Analysis and/or Interpretation - M.D., S.P., I.F.; Literature Search - M.D., S.P., I.F.; Writing Manuscript - M.D., S.P., I.F.; Critical Review - I.F.

Conflict of Interest: The authors have no conflicts of interest to declare.

Financial Disclosure: The authors declared that this study has received no financial support.

\section{References}

1. Vecchio GM, Amico P, Grasso G, Vasquez E, La Greca G, Magro G. Posttraumatic inflammatory pseudotumor of the breast with atypical morphological features: A potential diagnostic pitfall. Report of a case and a critical review of the literature. Pathol Res Pract 2011; 207: 322-326. (PMID: 21371828) [CrossRef]

2. Coffin CM, Watterson J, Priest JR, Dehner LP. Extrapulmonary myofibroblastic tumour (inflammatory pseudotumour). Am J Surg Pathol 1995; 19: 859-872. (PMID: 7611533) [CrossRef]

3. Pettinato G, Manivel JC, Insabato L, De Chiara A, Petrella G. Al. Plasma cell granuloma (inflammatory pseudotumor) of the breast. Am J Clin Pathol 1988; 90: 627-632. (PMID: 3177278) [CrossRef]

4. Yip CH, Wong KT, Samuel D. Bilateral plasma cell granuloma (inflammatory pseudotumour) of the breast. Aust N Z J Surg 1997; 67: 300-302. (PMID: 9152166) [CrossRef]

5. Zardawi IM, Clark D, Williams G. Inflammatory myofibroblastic tumour of the the breast. A case report. Acta Cytol 2003; 47: 1077-1081. (PMID: 14674084) [CrossRef]

6. Bisceglia M, Fusilli S, Zaffarano L, Fiorentino F, Tardio B. Inflammatory pseudotumor of the breast. Report of a case and review of the literature. Pathologica 1995; 87: 59-64. (PMID: 7567168)

7. Chetty R, Govender D. Iinflammatory pseudotumor of the breast. Pathology 1997;2: 270-271. [CrossRef]

8. Gobbi H, Atkinson JB, Kardos TF, Simpson JF, Page DL. Inflammatory myofibroblastic tumour of the breast: report of a case with giant vacuolated cells. Breast 1999; 8: 135-138. (PMID: 14965731) [CrossRef]

9. Sastre-Garau X, Couturier J, Derré J, Aurias A, Klijanienko J, Lagacé R. Inflammatory myofibroblastic tumour (inflammatory pseudotumour) of the breast. Clinicopathological and genetic analysis of a case with evidence for clonality. J Pathol 2002; 196: 97-102. (PMID: 11748648) [CrossRef]

10. Haj M, Weiss M, Loberant N, Cohen I. Inflammatory Pseudotumor of the Breast: Case Report and Literature Review. Breast J 2003:9: 423-425. (PMID: 12968967) [CrossRef]

11. Zen Y, Kasahara Y, Horita K, Miyayama S, Miura S, Kitagawa S, Nakanuma Y. Inflammatory Pseudotumor of the Breast in a Patient With a High Serum IgG4 Level. Histologic Similarity to Sclerosing Pancreatitis. Am J Surg Pathol 2005; 29: 275-278. (PMID: 15644785) [CrossRef]

12. Ilvan S, Celik V, Paksoy M, Cetinaslan I, Calay Z. Inflammatory myofibroblastic tumor (inflammatory pseudotumor) of the breast. APMIS 2005;113: 66-69. (PMID: 15676017) [CrossRef]

13. Khanafshar E, Phillipson J, Schammel DP, Minobe L, Cymerman J, Weidner N. Inflammatory myofibroblastic tumor of the breast. Ann Diagn Pathol 2005; 9: 123-129. (PMID: 15944952) [CrossRef]

14. Akbulut M, Gunhan-Bilgen I, Zekioglu O, Duygulu G, Oktay A, Ozdemir N. Fine needle aspiration cytology of inflammatory myofibroblastic tumour (inflammatory pseudotumour) of the breast: a case report and review of the literature. Cytopathology 2007; 18: 384-387. (PMID: 17944956) [CrossRef]

15. Park SB, Kim KH, Shin HJ, Gong G. Inflammatory Pseudotumor (Myoblastic Tumor) of the Breast: A Case Report and Review of the Literature. J Clin Ultrasound 2009; 38: 52-55. (PMID: 19802887) [CrossRef] 
16. Kim SJ, Moon WK, Kim JH, Cho N, Chang CM. Inflammatory Pseudotumor of the Breast: a Case Report with Imaging Findings. Korean J Radiol 2009; 10: 515-518. (PMID: 19721838) [CrossRef]

17. Hill PA. Inflammatory pseudotumor of the breast: a mimic of breast carcinoma. The Breast J 2010; 16: 549-550. (PMID: 20701606) [CrossRef]

18. Sari A, Yigit S, Peker Y, Morgul Y, Coskun G, Cin N. Inflammatory Pseudotumor of the breast. Breast J 2011; 17: 312-314. (PMID: 21410588) [CrossRef]

19. Chougule A, Bal A, Das A, Singh G. IgG4 related sclerosing mastitis: expanding the morphological spectrum of IgG4 related diseases. Pathology 2015; 47: 27-33. (PMID: 25474510) [CrossRef]

20. Greenleaf EK, Williams NC, Leung AM. Inflammatory pseudotumor of the breast. Am Surg 2016; 82: e106-e107. (PMID: 27215709)

21. Goto W, Kashiwagi S, Takada K, Asano Y, Morisaki T, Takashima T, Noda S, Onoda N, Ohsawa M, Hirakawa K, Ohira M. A Case of Inflammatory
Pseudotumor of the Mammary Gland. Gan To Kagaku Ryoho 2016; 43: 2029-2031. (PMID: 28133211)

22. Senie RT, Rosen PP, Lesser ML, Snyder RE, Schottenfeld D, Duthie K. Epidemiology of breast carcinoma II: factors related to the predominance of left-sided disease. Cancer 1980; 46: 1705-1713. (PMID: 7417963)

23. Reis-Filho JS. Cytokeratin-positive inflammatory myofibroblastic tumour of the breast or low-grade spindle cell metaplastic breast carcinoma: what are the diagnostic criteria, anyway? J Pathol 2003; 200: 269-272. (PMID: 12754748) [CrossRef]

24. Hamano H, Kawa S, Horiuchi A, Unno H, Furuya N, Akamatsu T, Fukushima M, Nikaido T, Nakayama K, Usuda N, Kiyosawa K. High serum IgG4 concentrations in patients with sclerosing pancreatitis. N Eng J Med 2001; 344: 732-738. (PMID: 11236777) [CrossRef] 